\title{
Regional climatic and North Atlantic Oscillation signatures in West Virginia red cedar over the past millennium
}

\author{
Rosanne D'Arrigo ${ }^{\text {a,* }}$, Kevin J. Anchukaitis ${ }^{\text {a }}$, Brendan Buckley ${ }^{\text {a }}$, Ed Cook ${ }^{\text {a }}$, Rob Wilson ${ }^{\text {a,b }}$ \\ a TRL-LDEO, Palisades, NY, USA \\ ${ }^{\mathrm{b}}$ University of St. Andrews, UK
}

\section{A R T I C L E I N F O}

Article history:

Accepted 14 July 2011

Available online 27 July 2011

Keywords:

dendrochronology

North Atlantic Oscillation

red cedar

climate change

\begin{abstract}
A B S T R A C T
We describe a millennial length ( 1500-yr) tree-ring chronology developed from West Virginia (WVA), USA red cedar (Juniperus virginiana) ring widths that is significantly correlated with local to regional temperature and precipitation for the region. Using ensemble methods of tree-ring standardization, above average ring widths are indicated for the period between 1000 and $1300 \mathrm{CE}$, the approximate time of the Medieval Climate Anomaly (MCA), the most recent major warm episode prior to the modern era. The chronology then transitions to more negative overall growth persisting through much of the subsequent period known as the Little Ice Age (LIA). While WVA cedar growth levels during the MCA are broadly similar to the 20th century mean, the most positive values during the MCA are associated with RCS-standardized chronologies, which pseudoproxy tests reveal are likely biased artificially positive, warranting further investigation. This cedar record is significantly correlated with the NAO, due to the tendency for warmer, wetter conditions to occur in the eastern-central USA during the NAO's positive phase. These types of conditions are inferred for this cedar chronology during the MCA period, during which NAO reconstructions suggest a persistently-positive NAO state.
\end{abstract}

(c) 2011 Elsevier B.V. All rights reserved.

\section{Introduction}

The North Atlantic sector features great atmosphere-ocean variability that significantly impacts the climate of the basin and adjacent land areas across a range of spatial and temporal scales (Hurrell, 2008; Paz et al., 2008; Semenov et al., in press). Related severe drought/flood and cold/heat extremes, and persistent decadal and longer-term circulation anomalies across the region have profound effects for human populations and the ecosystems upon which they depend (Sutton and Hodson, 2005; Durkee et al., 2008). Much of this variability is linked to two dominant climatic modes: the North Atlantic Oscillation (NAO), usually defined as the sea level pressure (SLP) differential between the Icelandic Low and Azores High (Hurrell, 2008; Hurrell and Deser, 2009); and the Atlantic Multidecadal Oscillation (AMO), the dominant low-frequency mode of North Atlantic sea surface temperature or SST (Delworth and Mann, 2000; Enfield et al., 2001; Knight et al., 2005, 2006). Model simulations suggest that much of this low-frequency variability is forced by the internal dynamics of the Atlantic's thermohaline meridional overturning circulation (AMOC), and/or by greenhouse warming or other radiative forcing (Delworth and Mann, 2000; Knight et al., 2006; Delworth, 2009).

\footnotetext{
* Corresponding author.

E-mail address: rdd@Ideo.columbia.edu (R. D'Arrigo).
}

Instrumental records have been employed to better understand these phenomena (e.g. Hurrell, 2008), but their limited length makes them inadequate for inferring information about long-term North Atlantic variability prior to the past $100-150$ years. Annual, precisely-dated tree-ring chronologies, ice cores and other proxies, as well as documentary records, have helped augment instrumental information on the NAO for prior centuries (e.g. Cook et al., 1998; Appenzeller et al., 1998; Cullen et al., 2001; Cook et al., 2002; Luterbacher et al., 2002a,b; Fortin and Lamoureux, 2008), and for the AMO dating back to the 1500s (Gray et al., 2004). However, very few such proxies for the North Atlantic sector date back to the Medieval Climate Anomaly (MCA, approximate interval 800-1300 CE), a time of noteworthy temperature and precipitation anomalies in many areas of the globe that has potential relevance as a natural analog for anthropogenic warming (Diaz and Barriopedro, this volume). Because information about the climate of this episode is still so limited, many questions remain unresolved regarding the nature, spatial extent and causal mechanisms for climate anomalies during the MCA (Diaz and Barriopedro, this volume, MCA Special Issue, this volume).

A recent reconstruction based on Moroccan tree rings and Scotland speleothems (Trouet et al., 2009) purports to resolve centennial variability in the NAO over the past millennium and is one of the few such records that extends back to the MCA. The Trouet et al. (2009) record demonstrates a transition from a persistently positive NAO during the MCA to negative NAO conditions during the subsequent Little Ice Age (LIA) around 1300-1450 CE. They argue that this 
positive NAO state may have been initiated by La Niña-like conditions in the eastern tropical Pacific as a response to a proposed increase in radiative forcing via a thermostat mechanism, which may have helped cause an amplified AMOC and persistently positive NAO state during the MCA. This theory was previously put forward to account for megadrought-type conditions in the western USA during the MCA (Cook et al., 2004; Seager et al., 2007). Warm North Atlantic SSTs and a positive state of the AMO have also been inferred for the MCA, with various marine proxies indicating warmer conditions across the North Atlantic basin at this time, which would tend to enhance drought over the central-western USA (Oglesby et al., this volume). However, Touchan et al. (2010) did not identify an exceptionally dry Medieval Epoch in Morocco, using a similar network of northwestern Africa tree ring chronologies as utilized by Trouet et al. (2009).

While distal from its centers of action, eastern-central North America is a region that is nevertheless significantly impacted by the NAO. The NAO's positive phase is associated, mainly during winter and spring, with warm anomalies (and a tendency for increased rainfall) over the central/eastern USA, with opposite conditions for its negative phase (Fig. 1; http://www.ldeo.columbia.edu/res/pi/NAO/; Banfield and Jacobs, 1998; Fye et al., 2006; Durkee et al., 2008). Climatically-sensitive tree-ring records from this region have been shown to reflect temperature and moisture conditions linked to the NAO during the colder months of greatest variability of the North Atlantic climate system (Fig. 1, Cook et al., 2002). The NAO can also impact climate in the eastern-central USA during the summer months, via the effects of the expanded subtropical Azores pressure cell or Bermuda High (Folland et al., 2009). The AMO impacts conditions over the United States via blockage of moisture from the Gulf of Mexico, generally causing drought in the central and western USA (Gray et al., 2004; Oglesby et al., this volume). AMO-related moisture impacts over the eastern USA, however, are somewhat variable (e.g. Enfield et al., 2001; Gray et al., 2004; Oglesby et al. this volume). There is a tendency for warmer temperatures in this region during its positive phase (e.g. Sutton and Hodson, 2005).

\section{The West Virginia red cedar ring-width chronology}

Well dated, high resolution millennial climate proxies are relatively scarce for the eastern North American region of the North Atlantic rim. To provide additional long-term climatic information for the past millennium for this region, we describe a tree-ring chro- nology for West Virginia (WVA) in the eastern USA, derived from annual ring width measurements of samples of living and subfossil wood. It is based on collections obtained from old growth eastern red cedar (Juniperus virginiana L.) trees from three closely adjacent sites (knobs, or rounded hills, elevations $\sim 650-800 \mathrm{~m}$ ) in the Appalachian Mountain range of WVA (Fig. 2). These are relict sites where the trees have escaped logging or other disturbance. The samples were collected about a decade ago as part of the TRL-LDEO's EASTNET project (http://www.ldeo.columbia.edu/tree-ring-laboratory/treering-research/sites-species), and span the period from 481-1999 CE. These data were also utilized in the North American Drought Atlas (NADA, Cook and Krusic, 2004). These data have been used to explore the spatio-temporal characteristics of climate and drought across this region, but have not been extensively utilized for evaluation of longterm signatures related to North Atlantic climate (but see Maxwell et al., 2010).

The chronology is a composite of 173 individual core series from three adjacent elevated areas (knobs): the Cedar (CKD, 64 cores; CKJ, 26), Moser (MKD, 22 cores) and Bible Knob (BKD, 33 cores) sites, as well as an additional 28 samples from this location, sampled decades earlier. The living and subfossil wood series cross-date well with each other (overall series correlation in COFECHA, the computer-assisted dating program (Holmes, 1983), is 0.55). The raw data were then combined into one data set.

As outlined below, we have standardized the raw measurements for this location in order to resolve annual to centennial scale variability (c.f. Briffa and Melvin, 2011), and apply this record to infer the expression of regional climatic and NAO-related variability over WVA and vicinity during the past millennium.

\subsection{Tree-ring standardization}

In order to preserve any multi-centennial-length variability in the WVA cedar record, we standardized the ring-width measurements using several different methodologies in an ensemble approach (Fig. 3). These methods include the Friedman (1984) Super-Smoother (9), negative exponential curve fitting with and without application of an adaptive power transform (Cook and Peters, 1997), and the Regional Curve Standardization (RCS) method with and without a second detrending for contemporaneous growth rate biases (Cook and Kairiukstis, 1990; Briffa and Melvin, 2011). RCS is being increasingly utilized to preserve low-frequency climate information
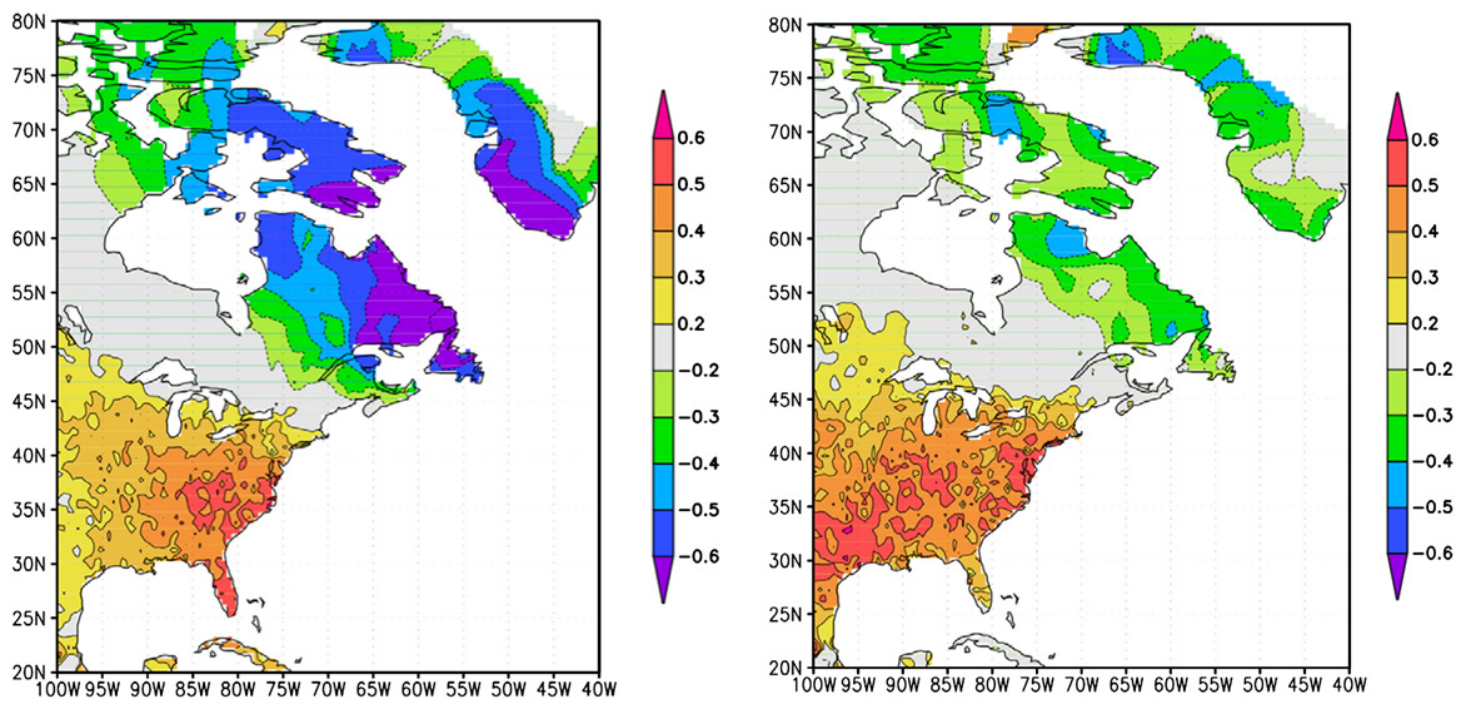

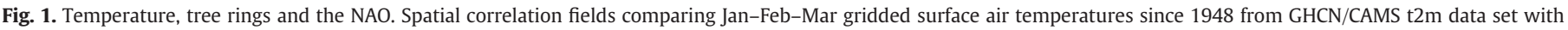

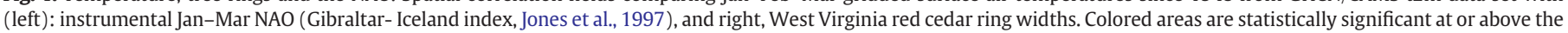
$90 \%$ level. 


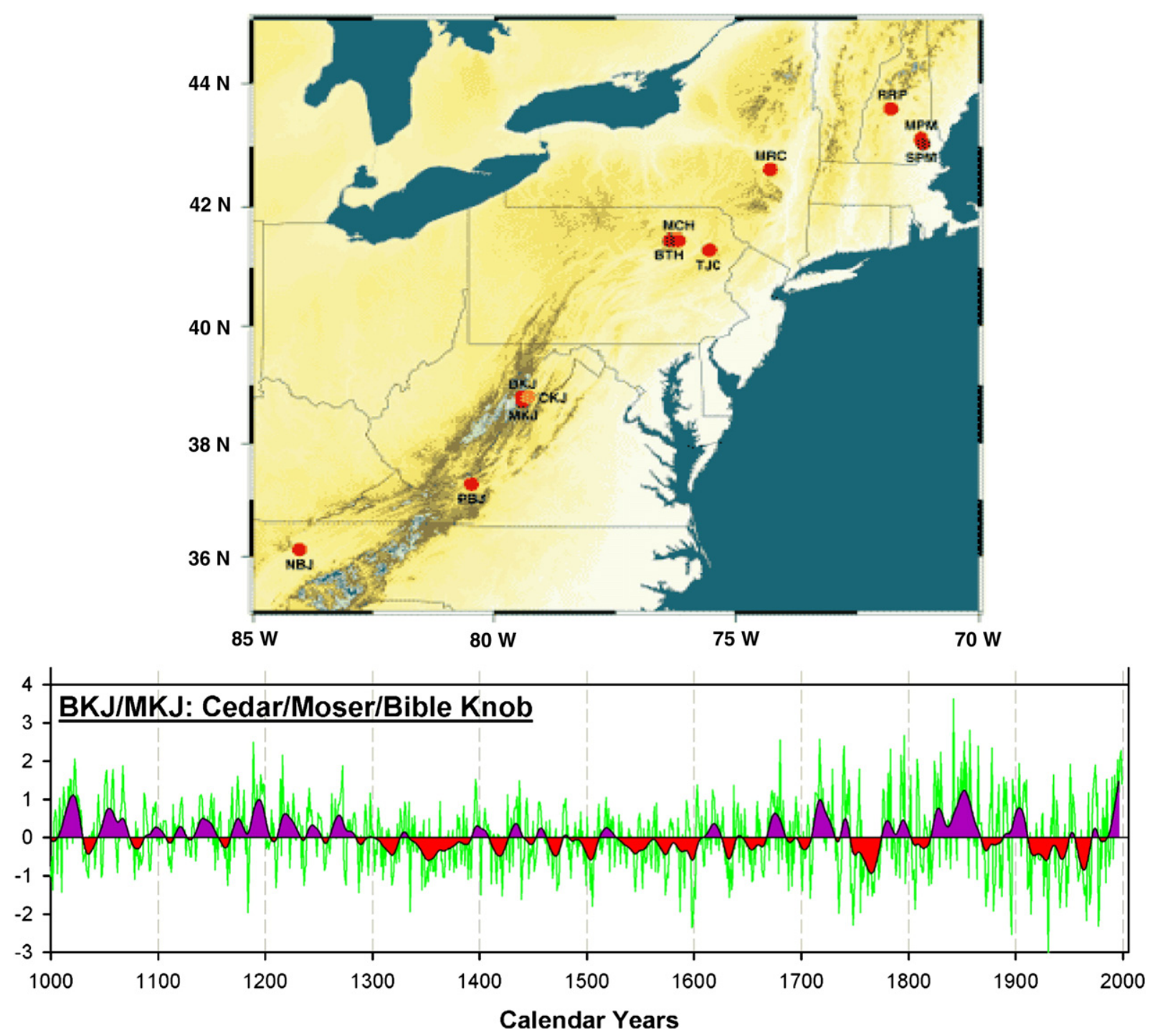

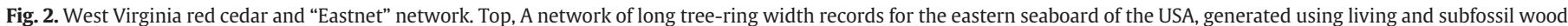

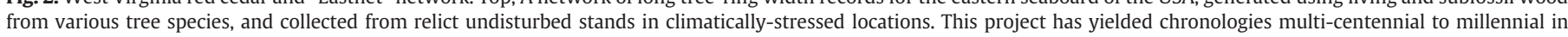

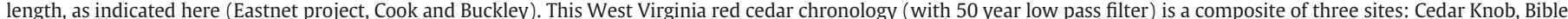

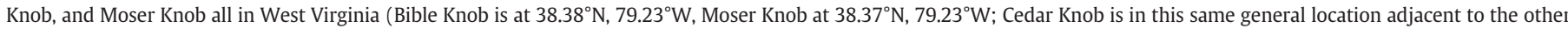

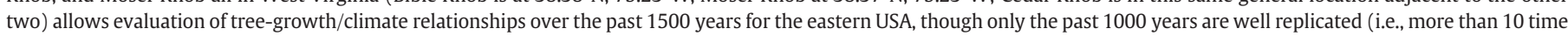
series, eps $>0.85$ ). The series shown in this figure was standardized using RCS, followed by subtraction of the long-term mean (see text).

where it is present, at periods that exceed the mean segment length of individual tree-ring series (Cook et al., 1995; Esper et al., 2002; Briffa and Melvin, 2011). Complicating this effort, however, is that the cedar record is rather heterogenous in structure, as it includes both living and subfossil wood, with samples spread over three adjacent sites in rugged terrain. Potential end effect bias can result from such features - for example, due to varying growth patterns in trees of the same biological age. Termed "differential contemporaneous growth rate bias", this can occur if individual growth curves for older trees, entering at the beginning of a chronology, fall below the mean regional growth curve used in RCS (Briffa and Melvin, 2011).

The time series that comprise the ensemble (Fig. 3) demonstrate common annual to multidecadal and longer-term variability in the WVA cedar ring widths over time. All chronology versions generally show elevated tree growth indices during the MCA period from 1000 to 1250 , transitioning to lower values in the LIA around 1250 and with higher overall subsequent growth departures in more recent centuries and since the onset of the 19th century. The middle (LIA) interval, particularly from around $1300-1600$, generally reveals rela- tively reduced ring widths and less variance than either the MCA or recent period. Interestingly, there is good agreement between the various ensemble series and the independent NAO reconstruction of Luterbacher et al. (2002b, Fig. 3) during their period of overlap (1500-1658).

We selected the RCS with a second linear mean detrending in order to compare the chronology with local to regional scale climatic and North Atlantic indices (Figs. 2, 3). This version of the WVA chronology has adequate sample size (as indicated by expressed population signal or eps values exceeding 0.85 - Cook and Kairiukstis, 1990) since around $1000 \mathrm{CE}$. It is also very similar to a gridded reconstruction of the summer PDSI for the state of WVA generated as part of the North American drought atlas (NADA, Cook and Krusic, 2004), based on this cedar series as well as other chronologies.

\section{WVA cedar chronology and climate indices}

WVA cedar growth is sensitive to both moisture and temperature, with the sign of these relationships changing with the season. For the 


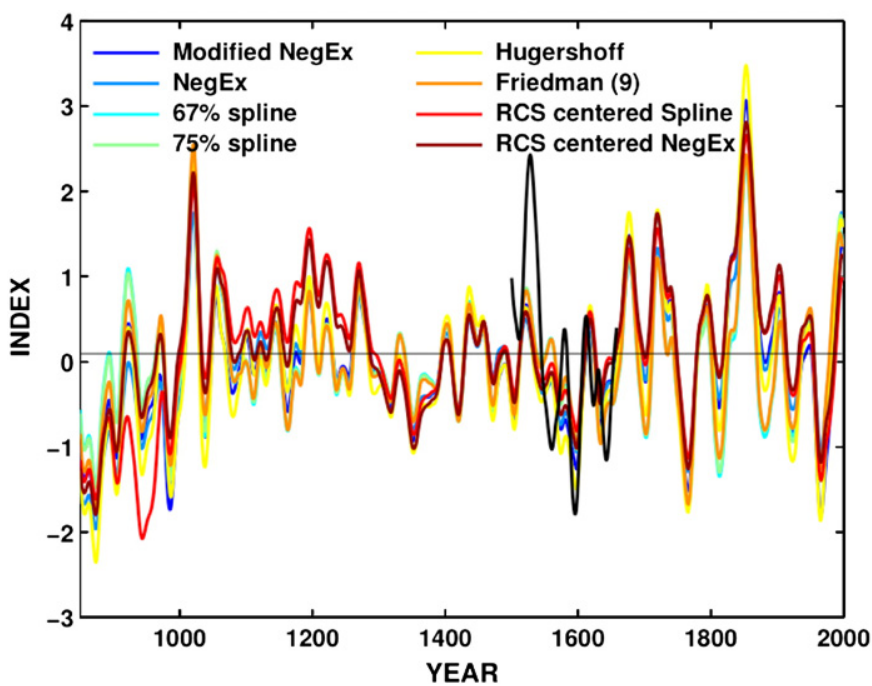

Fig. 3. Ensemble results using various detrending methods of tree-ring standardization of the West Virginia red cedar ring-width composite chronology for the past millennium used to infer past NAO variability, with 30 -year smoothing. The black line is the NAO reconstruction of Luterbacher et al. (2002a,b).

colder months, ring width correlates positively with both temperature and precipitation, while in the warmer spring and summer months of the growing season it correlates negatively with temperature and positively with precipitation, based on Charleston, WVA Historical Climate Network (HCN, Vose et al., 1998) station data and the gridded Palmer Drought Severity Index or PDSI (Dai et al., 2004, Table 1). The positive relationships with climate in the colder months are consistent with positive NAO-type conditions, while those during or just prior to the growing season indicate a tendency for drought stress at this time.

The WVA chronology also correlates significantly with various North Atlantic indices (Table 1). These correlations are positive, consistent with a possible link between favorable WVA cedar growth and the positive phase of the NAO. Instrumental temperature, precipitation and PDSI data for Charleston, West Virginia also compare positively and significantly with instrumental indices of the NAO (Table 1). However, it is important to note that these correlations are generally stronger after around the middle 20th century, indicating some there may be some time instability in the NAO-cedar tree growth relationship (most likely due to changing NAO teleconnections: see also Cook et al., 2002).

Table 1

Correlations between WVA red cedar chronology and local and regional North Atlantic climate indices. Seasons indicated are those for which the correlation is strongest for a particular dataset or comparison.

\footnotetext{
Local climate indices Charleston, WVA, $38.4^{\circ} \mathrm{N}, 81.6^{\circ} \mathrm{E}$

Rainfall: May-Jun n 107, r 0.52, n 44, 0.0000

Temperature: Dec-Mar n 50, r 0.65, n 44, 0.0000

NAO indices

NAO-Azores index: Dec-Mar, n 134, r 0.36, 0.0000

Climate Prediction Center's Dec-Mar NAO: n 50, r 0.58, 0.0000

AO SLP index: Jan-Mar, n 50, r 0.54, 0.0001

Bermuda temperatures: Feb-Jun, n 49, r 0.50, 0.001

Northern Scotland precipitation (a particularly sensitive NAO indicator - Hadley

Centre, 1931-now, Jan-Mar, n 69, r 0.50, 0.0000)

N Scotland precipitation and CRU Jan NAO, n 78, r 0.85, 0.0000

Local WVA Instrumental Data and NAO

Charleston WVA tmp and north Scotl precip: Dec-Feb, n 74, r 0.55, 0.0000

Charleston WVA ppt and north Scotl precip: Dec-Feb, n 74, r 0.37, 0.002

Charleston, WVA ppt vs CRU Icel-Gibr NAO Dec-Feb, n 113, r 0.27, 0.004

detrended n 113, r 0.26, 0.01

Charleston, WVA ppt vs Casablanca, Morocco precip Dec-Feb, n 92, r - 0.21,

0.050 (detrended n 92, $-0.25,0.020$ )
}

\section{Spectral analysis}

Spectral analysis provides additional evidence for NAO and North Atlantic signals in the WVA cedar record. Using Multi-Taper Method or MTM analysis (Mann and Lees, 1996), we identified significant spectral power in the sub-decadal to decadal bands that have typically been associated with the NAO, at $\sim 8$ and $11 \mathrm{yr}$ (Fye et al., 2006; Hurrell, 2008). The Fye et al. (2006) study demonstrated that there is a strong, coherent 7-8 year mode between the NAO and the climate of the eastern-central United States, consistent with our results. A significant peak at $\sim 60$ years is consistent with observations of North Atlantic multi-decadal climate variability, including the AMO (Rajagopalan et al., 1998; Delworth and Mann, 2000) (Fig. 4).

\section{RCS and pseudoproxy analysis}

We performed a pseudoproxy analysis to test for the possibility that the RCS method can cause low-frequency artifacts due to trend distortion or contemporaneous growth rate bias in the cedar chronology, which could account for some component of the positive growth trends observed during the MCA (Fig. 5, Melvin and Briffa, 2008). For this purpose, pseudoproxy ring width series were generated using a synthetic random climatic data intended to mimic the long term behavior of the NAO index, computed using winter season SLP output from the coupled millennium simulation of the NCAR CSM 1.4 general circulation model (GCM) (Ammann et al., 2007). Growth curves were fit to the actual raw cedar tree-ring width series and these curves were combined with their respective pseudoclimate series to generate the pseudoproxies. The synthetic series were then used to develop a master site chronology using RCS as if they were actual tree ring data. The results indicate that the RCS procedure applied to the actual cedar chronology may have some positive bias, as it diverges notably from the target NAO climate field in the early part of the record (Fig. 5). This finding suggests that some component of the observed low-frequency variability in the cedar record may be an artifact of standardization bias alone, caused by the contemporaneous growth rate bias identified by Briffa and Melvin (2011). This possibility warrants further investigation.

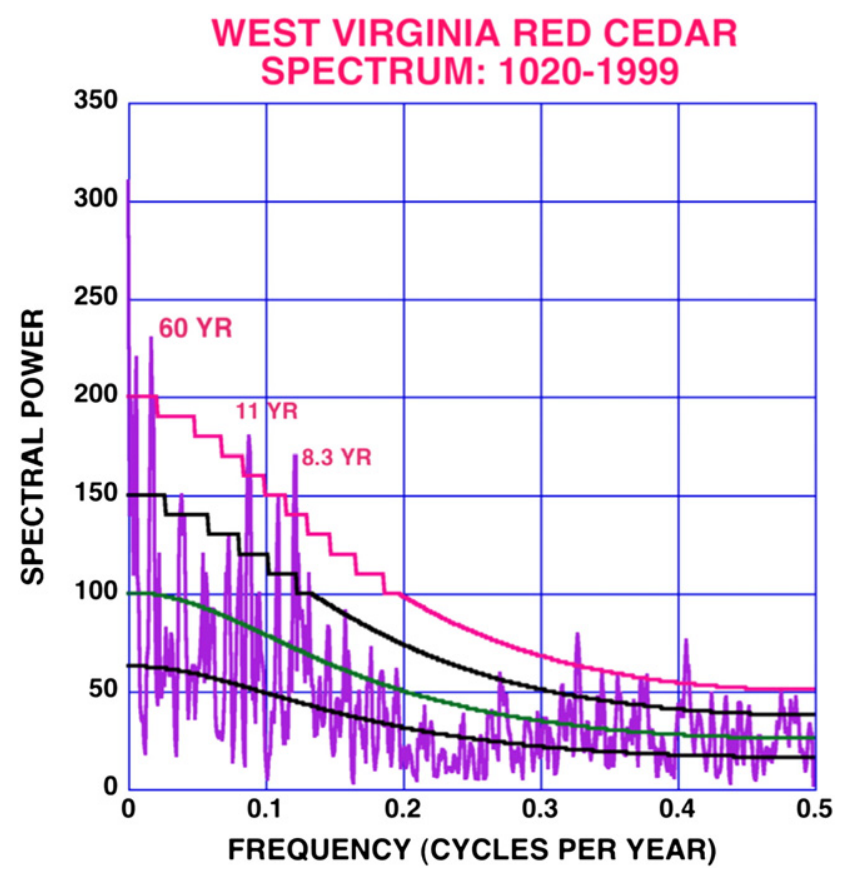

Fig. 4. Multi-taper method (Mann and Lees, 1996) spectral analysis of WVA cedar ring width chronology from 1020-1999. Significant spectral peaks at 8.3, 11 and $60 \mathrm{yr}$ have been identified in indices of North Atlantic climate variability. 


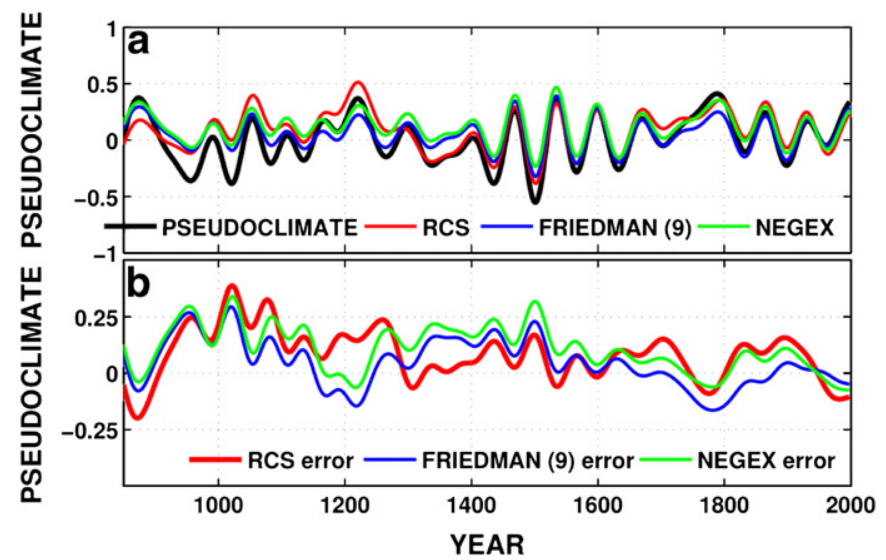

Fig. 5. Pseudoclimate model run compared to ensemble time series using different methods of standardization of West Virginia cedar chronology (top panel) and model error (bottom panel). Positive bias/error in the RCS version during the early part of the record is indicated.

\section{Discussion and conclusions}

We have described a red cedar ring width chronology for WVA, eastern USA that demonstrates substantial multi-decadal to centennial variability that we suggest is at least partly related to North Atlantic climate variability over the past millennium (Figs. 1-4, Table 1). These results are consistent with a recent study that reconstructed May precipitation using WVA red cedar tree-ring data, finding wetter (drier) than median conditions during the MCA and LIA, respectively, and a positive correlation with the winter NAO (Maxwell et al., 2010). The variability in the cedar chronology at first appears consistent with the previous study of Trouet et al. (2009), who suggested the existence of a positive NAO state during the MCA, followed by transition to negative NAO-type conditions during the LIA and a subsequent return to a more positive NAO state. Our results are inconsistent, however, with Trouet et al. (2009) in that the apparent transition in the mean NAO condition occurs perhaps a century earlier, near AD 1300.

Additionally, we caution that there are several caveats with this analysis. One is that the red cedar record is not situated within one of the two main centers of action of the NAO, and that other factors can impact climate and tree growth at this location to varying degrees and at different times (e.g. the El Niño-Southern Oscillation or ENSO, Pacific Decadal Oscillation or PDO; although these circulation features have relatively weak impacts over the eastern USA). Non-stationarities in the impact of the NAO on eastern USA climate could thus confound its signal at times over the past millennium. Another significant caveat is the evidence for some positive RCS-induced bias during the MCA (Fig. 5).

We have shown that the WVA cedar record is significantly correlated with relevant North Atlantic climate indices, indicating an NAO-type signal in this record. Additionally, its spectral features are broadly consistent with other time series of NAO-type variability. In particular, similar oscillatory modes have been observed for the NAO in instrumental and proxy records at around 7-8 years ( 7-10 yr: e.g. Moron et al., 1998; Cook et al., 2002; Fye et al., 2006), bi-decadal and multi-decadal time scales (at 20-68 yr; Luterbacher et al., 1999, 2002a,b). The Cook et al. (2002) cold season NAO reconstruction was based in part on tree-ring records from the eastern half of the USA, with significant spectra at 2-3, 3.97, and 7.75 years. A sub-decadal mode at $\sim 7-8$ years was also identified as being a coherent feature between central USA tree rings and the NAO (Fye et al., 2006), and at $\sim 65-80$ years for the AMO, in broad agreement with the cedar record (Delworth and Mann, 2000; Enfield et al., 2001; Hubeny et al., 2009).
A number of marine proxies from both the tropical Pacific and Atlantic Oceans provide supportive evidence for cooler (La Niña-like; e.g. Cobb et al., this volume) and warmer (positive AMO-type; Oglesby et al., this volume) SSTs, respectively, during the MCA. Confounding this issue, however, several of the western Pacific tropical proxies are inconsistent with this claim, showing evidence of more agreement with El Niño like conditions (Oppo et al., 2009; Tierney et al., 2010) or more frequent El Niño events (Moy et al., 2002; Conroy et al., 2009).

Of more direct relevance to the present study is an isotopic $\left(\mathrm{O}_{18}\right)$ speleothem record from a cave in WVA, not far from the WVA cedar site (Hardt et al., 2010). It is sensitive to hydroclimate variability associated with the summer NAO and Bermuda High pressure cell, and shows wetter conditions during the MCA and drier anomalies in the LIA, consistent with our cedar chronology results. A 2400-year reconstruction based on isotopic data from benthic foraminifera in Chesapeake Bay shows alternating warm and cold periods around the MCA (Cronin et al., 2010). While more paleoclimatic records are necessary in order to confirm or deny the theory of persistent La Niñalike conditions during the MCA, a persistently positive NAO may have occurred as a result of a direct increase in radiative forcing of the North Atlantic's atmosphere-ocean climate system, without the need to invoke the tropical Pacific La Niña teleconnection.

\section{References}

Ammann, C.M., Joos, F., Schimel, D.S., Otto Bliesner, B.L., Tomas, R.A., 2007. Solar influence on climate during the past millennium: results from transient simulations with the NCAR Climate System Model. Proc. Natl. Acad. Sci. U.S.A. $104(10), 3713$

Appenzeller, C., Stocker, T., Anklin, M., 1998. North Atlantic oscillation dynamics recorded in Greenland ice cores. Science 282, 446-449.

Banfield, C., Jacobs, J., 1998. Regional patterns of temperature and precipitation for Newfoundland and Labrador during the past century. Can. Geog. 42, 354-364.

Briffa, K.R., Melvin, T.M., 2011. A closer look at Regional Curve Standardisation of treering records: justification of the need, a warning of some pitfalls, and suggested improvements in its application. In: Hughes, M.K., Diaz, H.F., Swetnam, T.W. (Eds.), Dendroclimatology: Progress and Prospects Series, Vol 11, 1st Edition, 365 pp. Springer Verlag.

Cobb, K., H. Sayani, C. Charles, L. Edwards and H. Cheng. this volume. Coral records of central tropical Pacific temperature and hydrology during the Medieval Climate Anomaly.

Conroy, J.L., Restrepo, A., Overpeck, J.T., Steinitz-Kannan, M., Cole, J.E., Bush, M.B., Colinvaux, P.A., 2009. Unprecedented recent warming of surface temperatures in the eastern tropical Pacific Ocean. Nat. Geosci. 2 (1), 46-50.

Cook, E.R., Kairiukstis, L., 1990. Methods of dendrochronology: applications in the environmental sciences. Kluwer, Dordrecht.

Cook, E., Krusic, P., 2004. North American summer PDSI reconstructions. Technical Report 2004-045, IGBP-PAGES/World Data Center for Paleoclimatology: Data Contribution Series, Boulder, CO, USA.

Cook, E., Peters, K., 1997. Calculating unbiased tree-ring indices for the study of climatic and environmental change. Holocene 7, 361-370.

Cook, E., Briffa, K., Meko, D., Graybill, D., Funkhouser, G., 1995. The 'segment length curse' in long tree-ring chronology development for paleoclimatic studies. Holocene 5 , 229-237.

Cook, E.R., D'Arrigo, R.D., Briffa, K.R., 1998. The North Atlantic oscillation and its expression in circum-Atlantic tree-ring chronologies from North America and Europe. Holocene 8, 9-17.

Cook, E., D'Arrigo, R., Mann, M., 2002. A well-verified, multi-proxy reconstruction of the winter North Atlantic Oscillation index since AD 1400. J. Clim. 15, 1754-1764.

Cook, E., Woodhouse, C., Eakin, C., Meko, D., Stahle, D., 2004. Long-term aridity changes in the western United States. Science 306, 1015-1018.

Cronin, T., Hayo, K., Thunell, R., Dwyer, G., Saenger, C., Willard, D., 2010. The medieval climate anomaly and little ice age in Chesapeake Bay and The North Atlantic Ocean. Palaeogeogr. Palaeoclimatol. Palaeoecol. 297, 299-310.

Cullen, H., D'Arrigo, R., Cook, E., Mann, M.E., 2001. Multiproxy-based reconstructions of the North Atlantic Oscillation over the past three centuries. Paleoceanography 15, 27-39.

Dai, A., Trenberth, K., Qian, T., 2004. A global data set of Palmer Drought Severity Index for 1870-2002: relationship with soil moisture and effects of surface warming. J. Hydrometeorol. 5, 1117-1130.

Delworth, T., 2009. Decadal climate variability, predictability, and predictions - focus on the Atlantic. GFDL presentation, Mar 25.

Delworth, T.L., Mann, M.E., 2000. Observed and simulated multidecadal variability in the Northern Hemisphere. Clim. Dyn. 16, 661-676.

Diaz, H. and D. Barriopedro. this volume. MWP Symposium, Sept 2010, Lisbon.

Durkee, J., Frye, J., Fuhrmann, C., Lacke, M., Jeong, H., Mote, T., 2008. Effects of the North Atlantic Oscillation on precipitation-type frequency and distribution in the eastern United States. Theor. Appl. Climatol. 94, 51-65. 
Enfield, D.B., Mestas-Nunez, A., Trimble, P., 2001. The Atlantic multidecadal oscillation and its relation to rainfall and river flows in the continental U.S. Geophys. Res. Lett. 28, 2077-2081

Esper, J., Cook, E., Schweingruber, F., 2002. Low-frequency signals in long tree-ring chronologies for reconstructing past temperature variability. Science 295, 2250-2253.

Folland, C., Knight, J., Linderholm, H., Fereday, D., Ineson, S., Hurrell, J., 2009. The summer North Atlantic oscillation: past, present and future. J. Clim. 22, 1082.

Fortin, D., Lamoureux, S., 2008. Multidecadal hydroclimatic variability in northeastern North America since 1550 AD. Clim. Dyn.. doi:10.1007/s00382-008-0422-6.

Friedman, J., 1984. A variable span smoother. Dept. of Statistics, Stanford Univ. Tech. Rept. LCS5.

Fye, F., Stahle, D., Cook, E., Cleaveland, M., 2006. NAO influence on sub-decadal moisture variability over central North America. Geophys. Res. Lett. 33, L15707. doi:10.1029/ 2006GLO26656, 2006.

Gray, S., Graumlich, L., Betancourt, J., Pederson, G., 2004. A tree-ring based reconstruction of the Atlantic multidecadal oscillation since 1567 AD. Geophys. Res. Lett. 31. doi:10.1029/GL019932.

Hardt, B., Rowe, H., Springer, G., Cheng, H., Edwards, R., 2010. The seasonality of east central North American precipitation based on three coeval Holocene speleothems from southern West Virginia. EPSL 295, 342-348.

Holmes, R.L., 1983. Computer-assisted quality control in tree-ring dating and measurement Tree-Ring Bull. 43, 69-78.

Hubeny, J., King, J., Santos, A., 2009. Subdecadal to multidecadal cycles of Late Holocene North Atlantic climate variability preserved by estuarine fossil pigments. Geology 34, 569-572.

Hurrell, J., 2008. Decadal climate prediction: challenges and opportunities. J. Phys. Conf. Ser. 125,012018

Hurrell, J., Deser, C., 2009. North Atlantic climate variability: the role of the North Atlantic oscillation. J. Mar. Syst. 78, 28-41.

Jones, P.D., Jónsson, T., Wheeler, D., 1997. Extension to the North Atlantic Oscillation using early instrumental pressure observations from Gibraltar and South-West Iceland. Int. J. Clim. 17, 1433-1450.

Knight, J.R., Allan, R.J., Folland, C.K., Vellinga, M., Mann, M.E., 2005. A signature of persistent natural thermohaline circulation cycles in observed climate. Geophys. Res. Lett. 32, L20708. doi:10.1029/2005GL024233.

Knight, J., Folland, D., Scaife, A., 2006. Climate impacts of the Atlantic multidecada oscillation. Geophys. Res. Lett. 33, L17706. doi:10.1029/2006GL026242, 2006.

Luterbacher, J., Schmutz, C., Gyalistras, D., Xoplaki, E., Wanner, H., 1999. Reconstruction of monthly NAO and EU indices back to AD 1675. Geophys. Res. Lett. 26, 2745-2748.

Luterbacher, J., Xoplaki, E., Dietrich, D., Rickli, R., Jacobeit, J., Beck, C., Gyalistras, D., Schmutz, C., Wanner, H., 2002a. Reconstruction of sea level pressure fields over the eastern North Atlantic and Europe back to 1500. Clim. Dyn. 18, 545-561.

Luterbacher, J., Xoplaki, E., Dietrich, D., Jones, P., Davies, T., Portis, D., Gonzalez-Rouco, J. von Storch, H., Gyalistras, D., Casty, C., Wanner, H., 2002b. Extending North
Atlantic oscillation reconstructions back to 1500. Atmos. Sci. Lett.. doi:10.1066/ asle.2001.0044

Mann, M.E., Lees, J., 1996. Robust estimation of background noise and signal detection in climatic time series. Clim. Change 33, 409-445.

Maxwell, S., Hessl, A., Cook, E., Buckley, B., 2010. A 1248-year reconstruction of May precipitation for the Mid-Atlantic region using Juniperus virginiana Tree rings. Abstract, AGU Fall Meeting 2010, San Francisco.

Melvin, T.M., Briffa, K.R., 2008. A "signal-free" approach to dendroclimatic standardization. Dendrochronologia 26, 71-86.

Moron, V., Vautard, R., Ghil, M., 1998. Trends, interdecadal and interannual oscillations in global sea-surface temperatures. Clim. Dyn. 14, 545-569.

Moy, C., Seltzer, G., Rodbell, D., Anderson, D., 2002. Variability of El Nino/Southern Oscillation activity at millennial timescales during the Holocene epoch. Nature 420, 162-165.

Oglesby, R., S. Feng and $\mathrm{O} . \mathrm{Hu}$, this volume. New perspectives on the role of the AMO in MWP drought: Results from proxy data and climate model analyses. MCA Symposium

Oppo, D.W., Rosenthal, Y., Linsley, B.K., 2009. 2000-year-long temperature and hydrology reconstructions from the Indo-Pacific Warm Pool. Nature 460, 113-160. doi:10.1038/nature08233.

Paz, S., Tourre, Y., Brolley, J., 2008. Multitemporal climate variability over Atlantic Ocean and Eurasia: linkages with Mediterranean, West African climate. Atmos. Sci. Lett 9, 196.

Rajagopalan, B., Kushnir, Y., Tourre, Y., 1998. Observed decadal midlatitude and tropical Atlantic climate variability. Geophys. Res. Lett. 25, 3967-3970.

Seager, R., Graham, N., Herweijer, C., Gordon, A., Kushnir, Y., Cook, E., 2007. Blueprints for Medieval hydroclimate. Quat. Sci. Rev. 26, 2322-2336.

Semenov, V., Latif, M., Dommenget, D., Keenlyside, N., Strehz, A., Martin, T., Park, W., 2010. The impact of North Atlantic-Arctic multidecadal variability on Northern Hemisphere surface air temperature. J. Climate 23 (21), 5668-5677.

Sutton, R., Hodson, D., 2005. Atlantic Ocean forcing of North American and European summer climate. Science 309. doi:10.1126/science.1109496.

Tierney, J.E., Oppo, D.W., Rosenthal, Y., Russell, J.M., Linsley, B.K., 2010. Coordinated hydrological regimes in the Indo-Pacific region during the past two millennia. Paleoceanography 25, PA1102. doi:10.1029/2009PA001871.

Touchan, R., K. Anchukaitis, D. Meko, S. Attalah, C. Baisan and A. Aloul. 2010. Long-Term context for recent drought in northwestern Africa. Geophys. Res. Lett. 35: L13705 2008 http://dx.doi.org/10.1029/2008GL034264.

Trouet, V., Esper, J., Graham, N., Baker, A., Scourse, J., Frank, D., 2009. Persistent positive North Atlantic oscillation mode dominated the Medieval Climate Anomaly. Science 324, 78-80.

Vose, R. S., R. L. Schmoyer, P. M. Steurer, T. C. Peterson, R. Heim, T. R. Karl, and J. K. Eischeid. 1998. Global Historical Climatology Network, 1753-1990, ORNL/CDIAC-53, CDIAC NDP-041, Carbon Dioxide Information Analysis Center, Oak Ridge National Laboratory, Oak Ridge, Tennessee, U.S.A., 1992. doi:10.3334/ORNLDAAC/220. 